\title{
Characteristics of an Upper Jurassic Carbonate Ramp in the Northern Amu-Darya Basin
}

\author{
Yongyao Heㄹ, Han Mu1', Yuanyuan Kang1, Yingmin Wang², Bojiang Fan1 \\ ${ }^{1}$ School of Petroleum Engineering and Environment Engineering, Yan'an University, Yan'an, China \\ ${ }^{2}$ Ocean College, Zhejiang University, Hangzhou, China \\ Email:ndbw@yahoo.com.cn,ndbw12@163.com
}

How to cite this paper: He, Y.Y., Mu, H., Kang, Y.Y., Wang, Y.M. and Fan, B.J. (2018) Characteristics of an Upper Jurassic Carbonate Ramp in the Northern Amu-Darya Basin. International Journal of Geosciences, 9, 148-159. https://doi.org/10.4236/ijg.2018.92010

Received: May 7, 2017

Accepted: February 25, 2018

Published: February 28, 2018

Copyright $\odot 2018$ by authors and Scientific Research Publishing Inc. This work is licensed under the Creative Commons Attribution International License (CC BY 4.0).

http://creativecommons.org/licenses/by/4.0/

\section{(c) (i) Open Access}

\begin{abstract}
Overemphasizing the value of reefs in oil and gas exploration, reef-oriented geologists explain all carbonate platform deposits using the Wilson model. In their eyes, rimmed shelves are more valuable than carbonate ramps. However, organic banks are excellent reservoirs generated by carbonate ramps in the study area, as verified beyond doubt through petroleum exploration, such as this thesis, which investigates the genesis, types, and distribution of carbonate deposition in the north zone of the Amu-Darya Basin. Monoclinal palaeogeomorphology and rudists suggest shallow environments. Given that oolite shoals and rudist patch reefs were observed in the study area, the depositional system is interpreted to be a carbonate ramp. The Callovian-Oxfordian stage consists of nine lithofacies: oolitic limestone, skeletal limestone, micritic limestone, bioturbated limestone, and crystalline limestone, which are grouped into three facies associations presenting outer ramp, mid-ramp, and inner ramp facies associations. Five depositional sequences can be distinguished in the Callovian-Oxfordian stage. Each third-order depositional sequence is composed of transgressive systems tracts (TST) and highstand systems tracts (HST). The TST consists of mudstones with a higher response to natural gamma rays, whereas the HST contains various types of grainstone, with subordinate dolostone. The vertical and lateral distributions of sedimentary facies, and their interpreted depositional environments, revealed a ramp exhibiting a gradual southeast-northwestward environmental change from outer ramp, mid ramp, and inner ramp carbonate facies.
\end{abstract}

\section{Keywords}

Carbonate Ramp, Facies Associations, Sequence, Amu-Darya Basin

\section{Introduction}

Turkmenistan Amu Darya basin is one of the world's most famous oil and gas 
rich basins [1]. Carbonate deposits of hundreds of meters thick are developed widely in a shallow water carbonate platform setting and the most favorable exploration objectives are the carbonate reservoirs of the Upper Jurassic Callovian-Oxfordian [1]-[5].

In recent years, many geologists have been studied sedimentary facies [3] [6], reefs and shoal reservoirs [4] [7] [8], crack identification [9], tectonic evolution [10] in Callovian-Oxfordian Stage through drilling core description and logging, seismic data, and geological modeling technique, especially in the aspect of sequence [5] [11], which can be applied to discovery oil and gas in the Amu-Darya basin.

Cui Cui (2017) recognized three third-order shallowing-upward stratigraphic sequences in Callovian-Oxfordian Stage [5]. Wang Qiang (2014) recognized three third-order sequences, which can be further divided into transgressive systems tract (TST) and Highstand Systems Tract (HST) [11].

In terms of Sedimentary model, there are different views. Cui Cui (2005) and Wang Qiang (2014), et al. successively proposed Callovian-Oxfordian strata experienced the sedimentary evolution carbonate ramp [3] [5]. Zheng, Rong Cai determined that the Callovian-Oxfordian carbonates in the Amu Darya basin were deposited by platforms and characterized by the fore-edge slope [12]. Xu Wenli (2012) established the depositional model of "platform with open, rimmed and gently dipping slope" for the Callovian-Oxfordian carbonates. On top of that, many other researchers at home such as Cui Cui (2017), Nie Minglong (2016), Feng Lei (2009), and Zhang Xianwen (2010) et al. improved carbonate rimmed shelf pattern.

\section{Geological and Stratigraphic Setting}

The Amu-Darya basin occupies desert and semi-desert areas of southeast Turkmenistan, southwest Uzbekistan, and northwest Afghanistan; a small part of the basin is located in Iran (Figure 1). The basin area exceeds $43 \times 10^{4} \mathrm{~km}^{2}$, of which $36 \times 10^{4} \mathrm{~km}^{2}$ are in Turkmenistan and Uzbekistan [13].

The Amu-Darya basin, occupying the western part of Uzbekistan, eastern and central parts of Turkmenistan, north Afghanistan and north-eastern part of Iran, is located in southern Turan plate. It is bounded by the Kyzyl-Kum Range to the north, the Kopet Dag Range to the south, by the south-western branch of the Gissar Range to the east. In the west, the basin boundary runs along the western slope of the Central Karakum Arch (Figure 1).

This study area focuses on the northern region in the Amu Darya basin, including evolution Erzhu, Bukhara terraces, which belong to two second-order tectonic units of the Amu Darya basin (Figure 1).

The stratification can be divided into upper, middle and lower three tectonic sequences (Figure 2) based on two major unconformities and the structure-sedimentary characteristics [14].

Lower construction sequence, including the Permian-Triassic, composed mainly of acidic volcanic rocks and terrigenous clastic rocks, which are absent in 


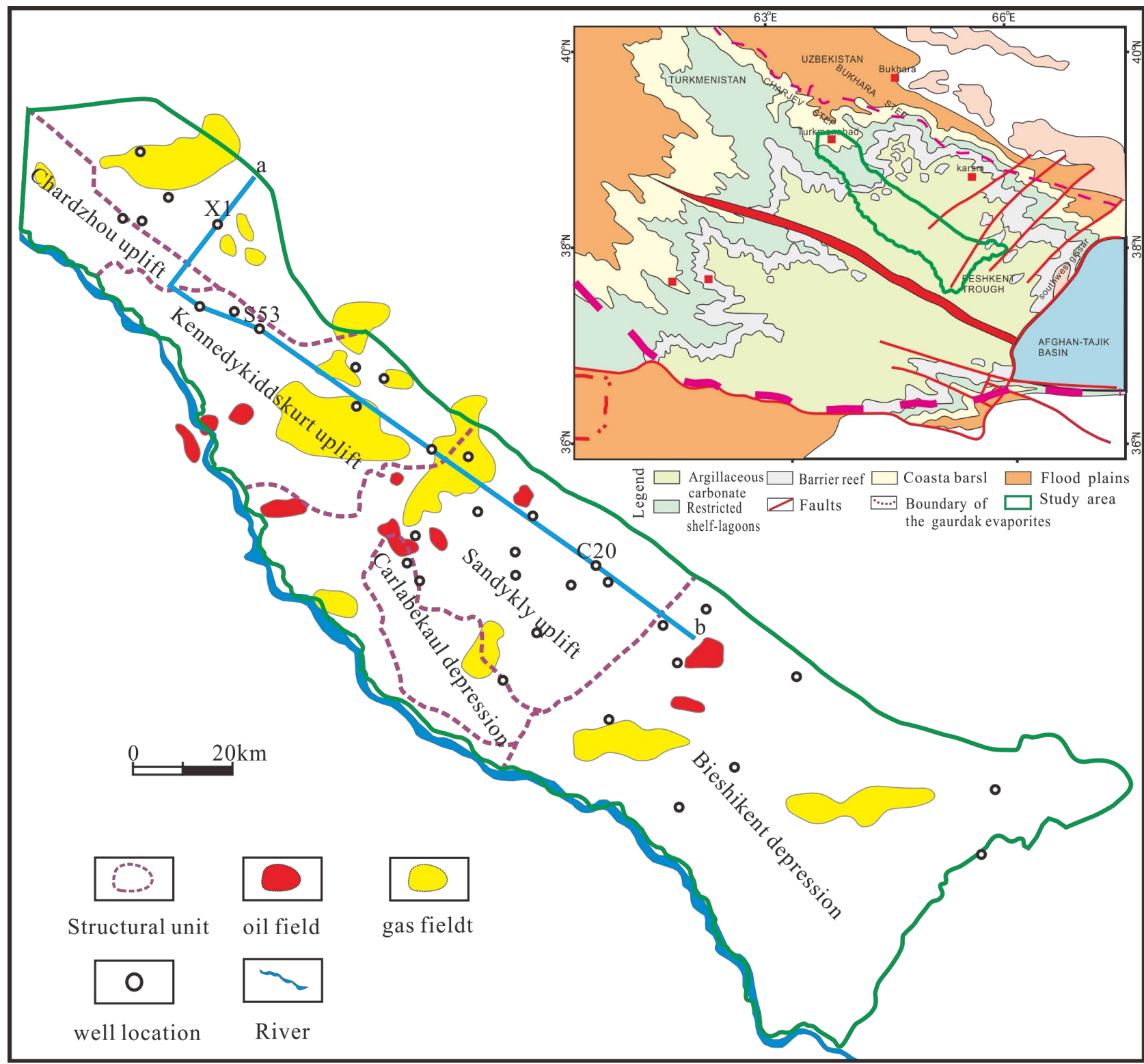

Figure 1. Structural elements and location map of the study area modified from [2] [5].

Bukhara terrace. The normal faults are well developed, accompanied by volcanic intrusion.

The middle tectonic sequences include Jurassic, Cretaceous, and Paleogene. The Lower Jurassic is represented by a sequence of inland fluvial-lacustrine siliciclastic rocks. The Upper Jurassic is dominated by limestones and evaporates. The Cretaceous lithology is mainly characterized by sand and mud interstratification. The Lower Paleogene can be divided into four lithological members: limestone and gypsum interbedded at the base, a large section of mudstone in the middle, and sandstone at the top. Cenozoic tectonic movements resulted in the development of faults and strongly folded strata.

The lower three tectonic sequences include Neogene and Quaternary. The inherited tectonic is well developed and local angular unconformity is clearly visible. 


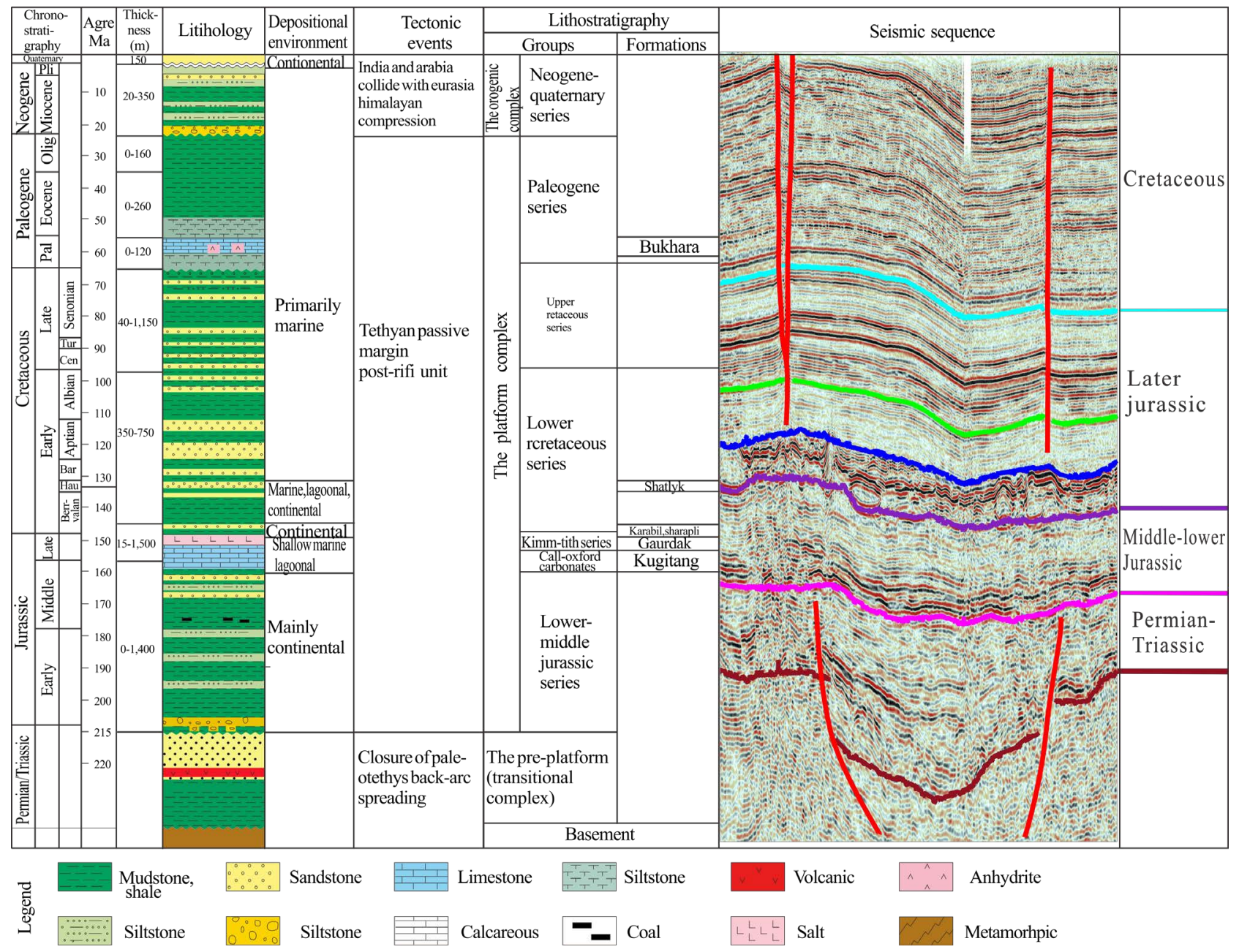

Figure 2. Tectonic sequence division in northern Amu-Darya Basin modified from [1].

During the Mesozoic Era, the Amu-Darya Basin was located at the marginal belt of the northern part of the Paleo-Tethys Ocean. The sedimentary and structural characteristics of the Amu-Darya Basin were subject to the formation and evolution of the Tethys orogenic belt and Tethya transgression. The evolution of the Amu-Darya Basin can be divided into three stages: the arc foreland basin development stage (late Permian to Triassic), the rift-arc extension stage (early Jurassic to Paleogene), and the foreland basin stage (Late Paleogene).

The structural evolution of the study area show that the CheckErzhu and Bukhara terraces were characterized by a wedge of sediment for a long time under conditions of continuous tectonic subsidence and regional tectonic stability prior to Eogene sediment [9] [10] [14] [15]. The neritic-bathyal environment gradually predominated in the studied area because of Jurassic transgression, resulting in Biologic limestone sediment.

\section{Facies Analysis}

\subsection{Lithology}

The petrographic investigation on the Callovian and Oxfordian revealed the 
presence of several the lithologies represented by listing in Table 1 .

\subsection{Facies Interpretation}

\subsubsection{Palaeogomorphic Geomorphology}

The structural evolution of the study area show that the CheckErzhu and Bukhara terraces were characterized by a wedge of sediment for a long time, under conditions of continuous tectonic subsidence and regional tectonic stability prior to Eogene sediment. The palaeogeomorphology during the Jurassic deposition period was the gentle slope whose slope is less than 1 (Figure 3). The neritic-bathyal environment gradually predominated in the studied area because of Jurassic transgression, resulting in Biologic limestone sediment.

\subsubsection{Facies Model}

According to the definition for carbonate ramp is adopted from Burchette and Wright (Burchette 1992) who defined: 1) an outer ramp below the storm wave base (SWB), 2) a mid-ramp between the SWB and the fair-weather wave base (FWWB), and 3) an inner ramp located above the FWWB. The palaeogeomorphic analysis and the lithological changes suggest a very low dipping slope without shelf breaks and gravity deposits, characterizing a carbonate ramp profile.

There's several evidence support that a mode of carbonate ramp can be established consistent with the geological character of the study area (Figure 4). Oolite was developed in the Callovian and Oxfordian and was lack of organic reefs. The allochthonous carbonate blocks and carbonate gravity flow for the line

Table 1. The main rock types of Callovian and Oxfordian in northern Amu-Darya Basin (from [9] [10] [14] [15]).

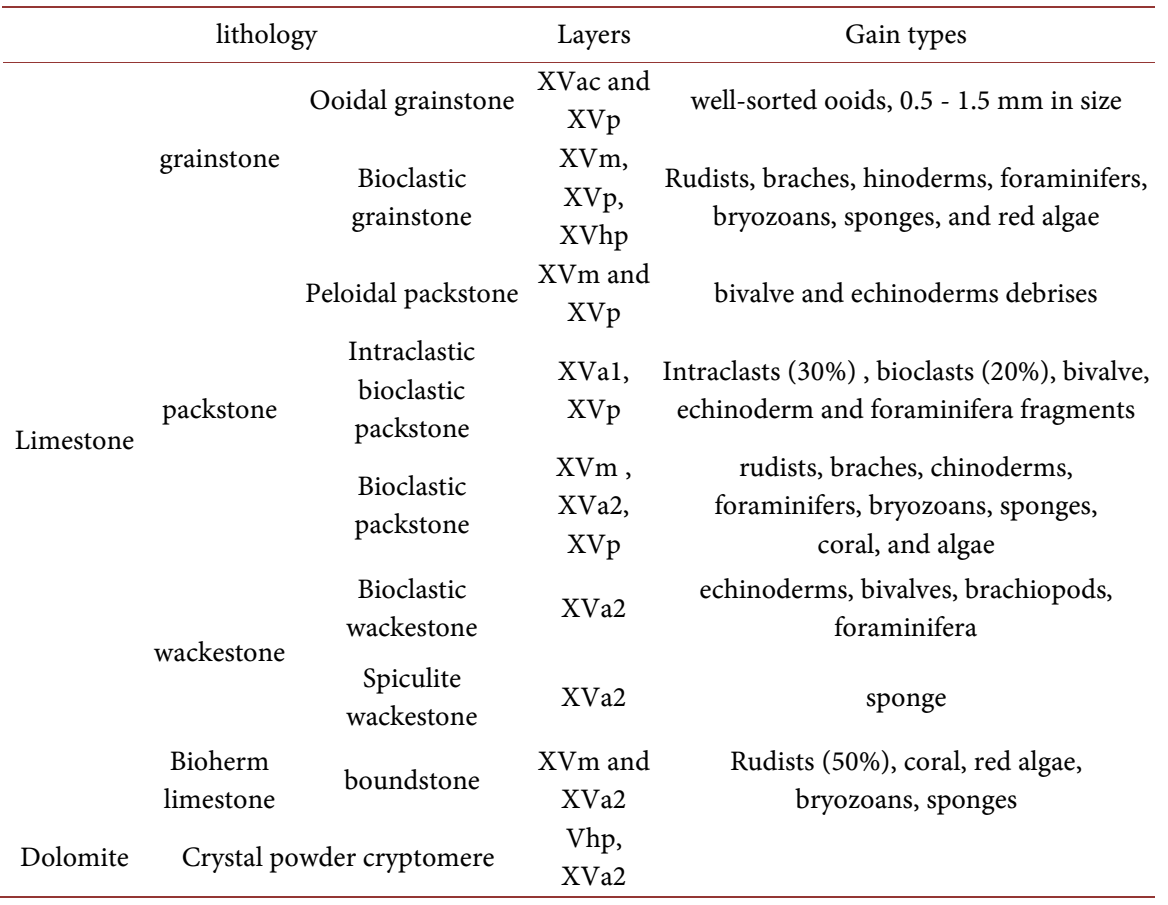




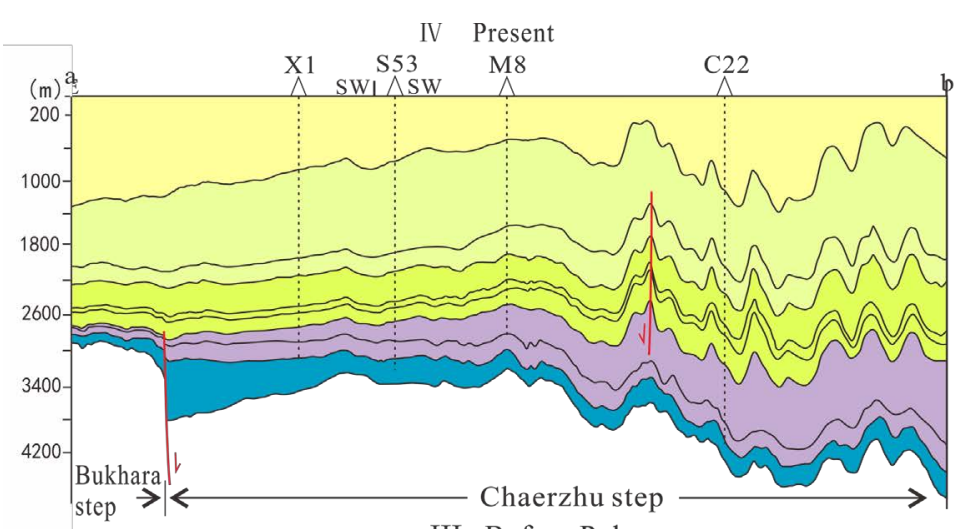

III Before Paleogene

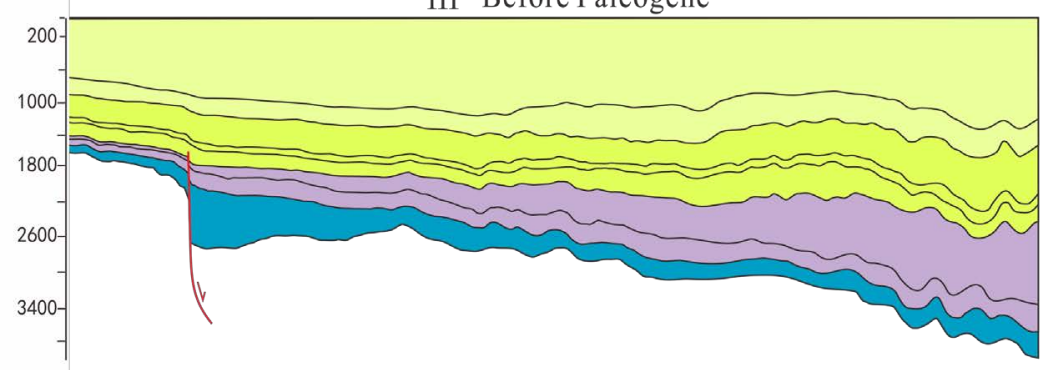

II Before Cretaceous

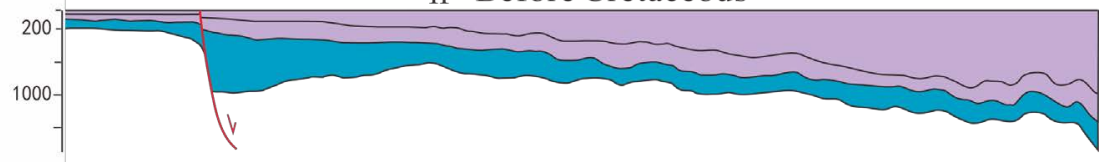

I Before Upper Ordovician

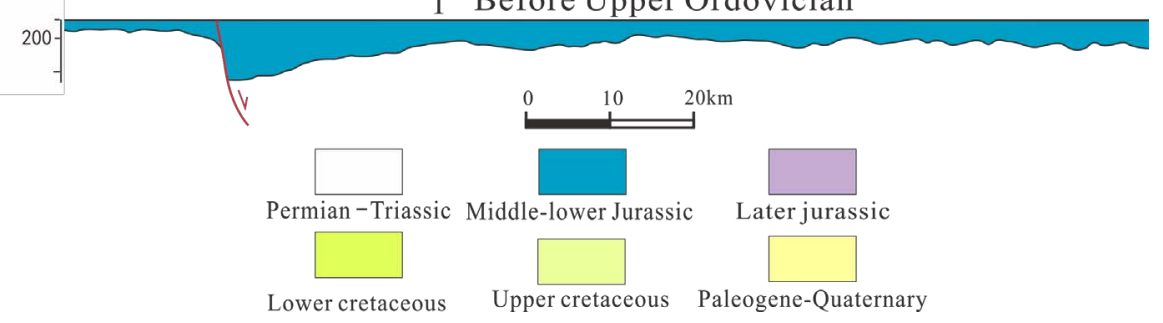

Figure 3. Tectonic evolution of in the northern of Amu-Darya Basin (section location shown as Figure 1).

sourced carbonate aprons and the point sourced carbonate submarine fans even alcirudites resulted from ancient events deposits in carbonate rimmed shelf won't found in scores of wells. There wasn't a topographic break in the study area during Jurassic Period use seismic horizon flattening technique.

\section{Outer ramp}

The facies is dominantly grey black mudstones with a generally sparse fauna (some gastropods). However, the meter-scale beds may contain more fossil debris and praealveolinids, as well as possess a wackestone texture. Microscopic observations of this facies showed the presence of sponge spicules, echinoids, red algae, annelids, and small benthic foraminifera.

The presence of marls indicates an open and distal environment, whereas the absence of hydrodynamic structures suggests a low-energy environment probably located below the SWB (storm weather base) on the outer part of the ramp. 


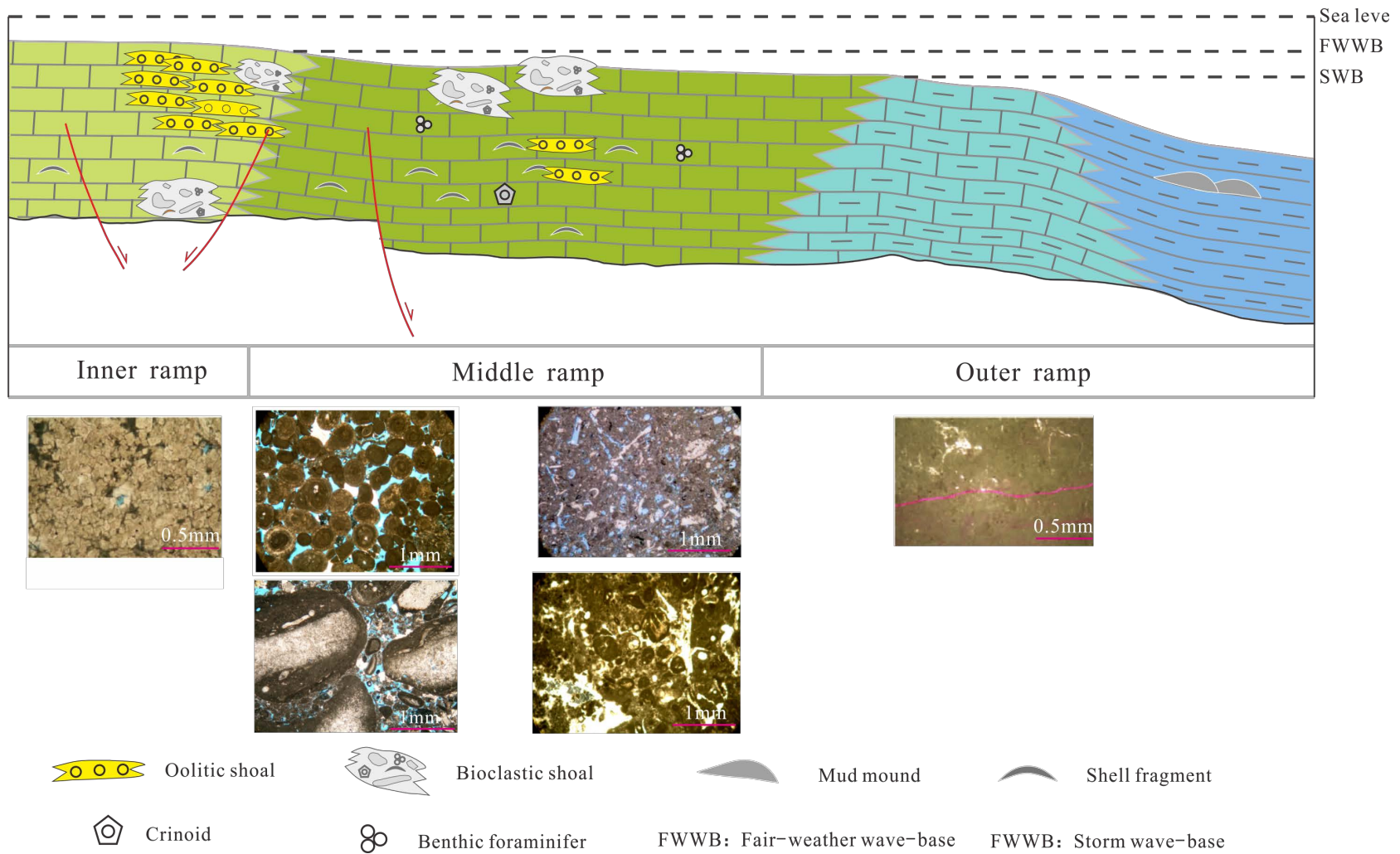

Figure 4. Schematic depositional profile of the Callovian-Oxfordian stage in northern Amu-Darya Basin (Photomicrographs from [5] [12]).

\section{Mid-ramp}

In the proximal margin, two facies types are distinguished: a low-energy facies, which is relatively muddier and bioturbated; and a high-energy facies, which is clean, coarse-grained bioclastic, and cross-bedded. The low-energy facies consists of wackestone to packstone, comprising bioclastic debris, peloids, benthic foraminifera (orbitolina, miliolids), as well as rudist and oyster fragments. A decimeter-scale bedding has a lower position.

\section{Inner ramp}

The high-energy facies consists of well-sorted, fine to coarse bioclastic grainstone with a rich faunal association dominated rudists. Small-scale to medium-scale cross-beddings are normal, and bedsets range from $1 \mathrm{dm}$ up to $1 \mathrm{~m}$. A sigmoidal cross-bedding has been observed, suggesting tidal influences. This facies is typical of relatively shallower positions.

At a larger scale (hundreds of meters), the mid ramp facies are organized in low-angle clinoforms showing a basinward transition from the cross-bedded high-energy facies to the bioturbated low-energy facies.

The paleowater depth of this setting ranges from just below to well within the reach of fair-weather wave base. Bioturbation and abundant benthic fauna (bivalves, brachiopods, echinoids, and crinoids) indicate normal oxygenation and salinities, which in turn suggest a sedimentation between the SWB and the FWWB. 


\section{Sequence Stratigraphy}

\subsection{Sequence Boundary}

The detailed seismic and sequence stratigraphy analysis carried out on the Callovian and Oxfordian reveals two kinds of sequence boundaries, the unconformity and the lithology transition surface. The unconformity surface were recognized using The through-well Seismic Profile a) (Figure 5), which shows weak seismic reflection as a result of the feeble difference in acoustic impendence above and below interface $\left(\mathrm{j}_{3 \mathrm{ttd}}, \mathrm{j}_{3 \mathrm{k}+\mathrm{o}}\right)$ and Local truncation under that are ordinarily found on eismic profile b) (Figure 5).

The data of well logging, drilling core were analyzed to identify the lithology transition surface, which marked the extent abnormal of GR, DT and RS logging curve (Figure 6). Each of them separates the underlying deep water carbonate deposits such as bioclastic packstone from the overlying bioclastic wackestones/mudstones.

The basal and top boundaries of sequences I and V are both characterized by a unconformity surface. The other sequence boundaries characterized by a lithofacies transitional surface.

\subsection{Sequence Stratigraphy}

Five depositional sequences are recognized in the Callovian-Oxfordian, i.e., SQ1, SQ2, SQ3, SQ4 and SQ5 by using log data, the thin sections and seismic data. A transgressive systems tract (TST) and a highstand systems tract (HST) are identified both within each sequence. The average durations of individual sequences are approximately $2 \mathrm{Ma}$.

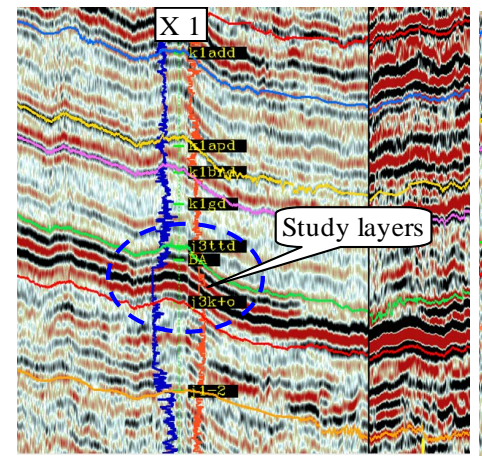

(a)

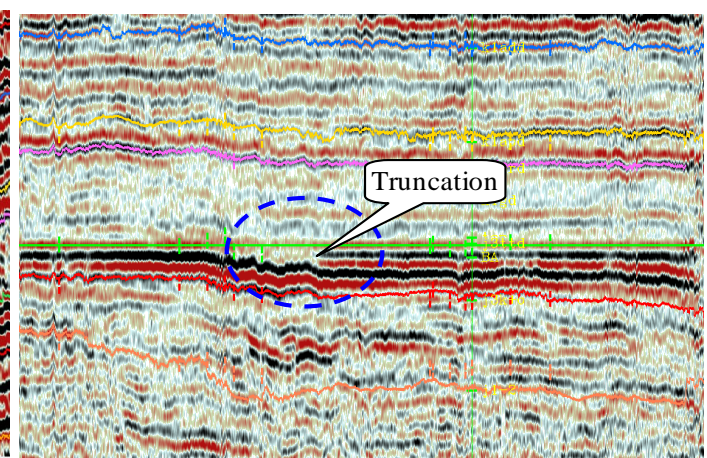

(b)

Figure 5. Seismic responses of the sequence boundary surface.

The first sequence boundary is the base of sequence SQ1 (Figure 6). This is a major unconformity that separates Upper Jurassic strata from the underlying Middle-Low Jurassic strata. An important change in the depositional history of the study area occurred from this surface. The underlying sediments consists of a series of clastics whereas the overlying sediments are almost pure carbonate. Small depositional discontinuity cavities occur at the top of SQ1, filled with 


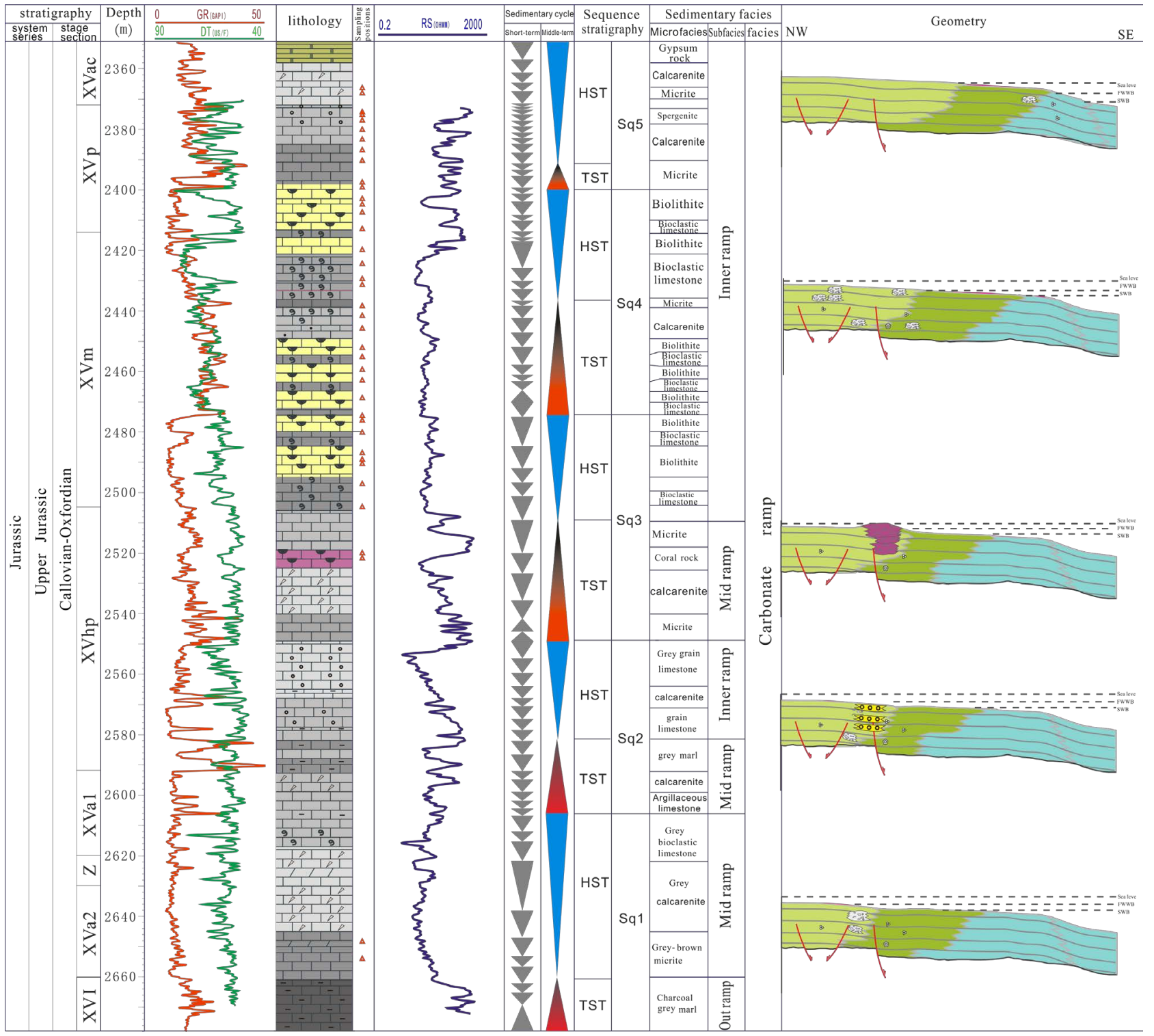

Figure 6. Sequence division of Upper Jurassic in northern Amu-Darya Basin (from S53 well).

wackestone with higher GR response. This sequence is composed of a TST and a HST, and its interface is maximum flooding surface marked by "skip" on high-resolution GR and RS logging traces, recording the progress of evolution and development Outer carbonate ramp facies transform to mid carbonate ramp facies.

SQ2 division owing to the remarkable charcteristics with wackestone with higher GR of several meters thick. The basal and top boundaries of this sequences characterized by a lithofacies transitional surface as a result the rate of eustatic sea-level fall matched the rate of subsidence. These depositional sequences are $60 \mathrm{~m}$ thick. Internally the sequences are basically composed of a transgressive lower part (TST) and a regressive upper part (HST), the upper part of grainstones. These were deposited broadly in high-energy shallow marine and 
lagoonal environments. The lower part of this sequence consists of $30 \mathrm{~m}$ of alternating grey skeletal packstones-wackestones.

SQ3 is $60-70 \mathrm{~m}$ thick and characterized by deepening and retrogradation of outer ramp facies immediately overlying on the bioclastic packstones of the upper part of SQ2, followed by shallowing and progradation of inner ramp facies. During the TST stage, an upward-deepening succession along the outer ramp is recorded by a sharp vertical change from mudstones in the underlying strata to bioclastic packstones/grainstones of shoals and/or bioclastic wackestones/mudstones of inner ramp facies. Corresponding wireline logs display an increasing trend in GR logging curve and a decreasing trend in RS logging curve.

SQ4 is composed of numerous meter-scale cycles and reflect changes within the inner ramp facies. The facies succession of this sequence can be divided into transgressive and highstand systems tracts, separated by deeper-water sediments which represent the maximum flooding zone. The TST comprises skeletal wackestone and skeletal limestone, whereas the HST mainly consists of oolitic limestone, with rudists, braches, hinoderms, foraminifers, bryozoans. The limestones with higher gamma ray responses in the lower part of the TST suggest that this part of the succession represents the maximum flooding and condensed section of the sequence.

SQ5 is at the end of Jurassic carbonate sedimentary, and its top boundary is an angular unconformity. The basal of this sequences characterized by a lithofacies transitional surface as a result of eustatic sea-level fall and subsidence. SQ5 consist of a TST and a greater thickness HST, which had been covered by protected low-energy platform environments during the deposition of the lower TST, and HST was also characterized by dolomite and gypsum of. These findings suggest that the facies belts were pushed landward.

Marine transgression began in late Bathonian or early Callovian period. After the deposition of the basal shale unit, carbonate sedimentation began and continued into the Oxfordian stage. During the Callovian-Oxfordian interval, the Amu-Darya basin was topographically partitioned into the deep-water sea that occupied the southeastern basin area and the shallow water area on its northern margins.

The Callovian to Oxfordian carbonate sequence is composed of inner, mid, and outer ramp facies, and includes oolitic, detrital, and algal limestones, dolomitic limestones, argillaceous limestones and marls, as well as local beds of anhydrite in the middle-upper Oxfordian section. Siliciclastic material is present and is locally dominant along the northern basin margin (Figure 6). From the Chardzhou step, the rudistid reef and shoal extend eastward and then southeastward, and separate the extensive shallow-water slop from the deep-water basin.

\section{Conclusions}

1) Various conditions facilitated the development of a ramp in the Amu-Darya Basin during the late Jurassic. Geomorphic characteristics and lithological asso- 
ciation sequences does not seem to support the point of view a rimmed platform with reef widely developed, and instead, proved that a carbonate ramp with shoal widely developed was deposited in the Callovian-Divesian stage.

2) The Callovian-Oxfordian carbonate ramp deposition included three types of subfacies, namely, outer, mid, and inner ramps, as well as some kinds of microfacies, such as oolite shoal, bioclastic shoal, inter-shoal mud. The inner ramp was the dominant part of a carbonate ramp, wherein the thickest sedimentary formations were deposited, and organic reefs, bioclastic shoals, and oolitic shoals were mainly developed.

3) The Callovian-Oxfordian stage experienced five transgressions on a large scale in the study area, and included five series of transgression-regression. In addition, cryptite, oolitic and biohermal limestones, and dolomite rock represented the maximum flooding event, the marine regression, and the most shallow water environment, respectively.

\section{Fund Program}

2016 National College Students' Innovation and Entrepreneurship Training Program (item number: 201610719023); 2016 Shaanxi Provincial College Students' Innovation and Entrepreneurship Training Program (item number: 1519).

\section{References}

[1] Ulmishek, G.F. (2004) Petroleum Geology and Resources of the Amu-Darya Basin, Turkmenistan, Uzbekistan, Afghanistan and Iran. U.S. Geological Survey Bulletin, 2201-H.

[2] Yu, Y.X., Yin, J.Y., Zheng, J.Z., et al. (2015) Division and Resources Evaluation of Hydrocarbon Plays in the Amu Darya Basin, Central Asia. Petroleum Exploration \& Development, 42, 819-826. (In Chinese) https://doi.org/10.1016/S1876-3804(15)30078-1

[3] Xu, W.L., Zheng, R.C., Fei, H.Y., et al. (2012) The Sedimentary Facies of Callovian-Oxfordian Stage in Amu Darya Basin, Turkmenistan. Geology in China, 39, 954-964. (In Chinese)

[4] Tian, Y.U., Xu, H., Zang, X.Y., et al. (2017) Sedimentsry Characteristics, Distribution Regularities and Main Controlling Factors of Carbonate Intra-Platform Shoal Reservoirs: A Case Study of Intra-Platform Shoal Gas Fields in the Amu Darya Basin. Earth Science Frontiers, 24, 312-321. (In Chinese)

[5] Cui, C., Zheng, R.C., Wang, Q., et al. (2017) A Sedimentology Study of Carbonate Reservoirs in Callovian-Oxfordian Stage, Amu Darya Basin, Turkmenistan. Oil \& Gas Geology, 4, 793-803. (In Chinese)

[6] Li, F., Jing, X., Zou, C., et al. (2017) Facies Analysis of the Callovian-Oxfordian Carbonates in the Northeastern Amu Darya Basin, Southeastern Turkmenistan. Marine \& Petroleum Geology, 88, 358-380. https://doi.org/10.1016/j.marpetgeo.2017.08.038

[7] Zhang, B., Zheng, R.C., Liu, H.N., et al. (2010) Characteristics of Carbonate Reservoir in Callovian-Oxfordian of Samandepe Gasfield, Tur-kmenistan. Acta Geologica Sinica, 84, 117-125. (In Chinese) https://doi.org/10.1007/s10114-010-8127-2 
[8] Zheng, R.C., Zhao, C., Liu, H.N., et al. (2010) Cathodoluminescence and Its Significance of the Callovian-Oxfordian Carbonate Rocks in Amu Darya Basin, Turkmenistan. Journal of Chengdu University of Technology, 37, 377-385. (In Chinese)

[9] Nie, M.L., Wu, L., Sun, L., et al. (2013) Salt-Related Fault Characteristics and Their Petroleum Geological Significance in Zarzhu Terrace and Its Adjacent Areas, the Amu Darya Basin. Oil \& Gas Geology, 34, 803-808. (In Chinese)

[10] Zhang, Z.W., He, Y.Y., Wang, C.S., et al. (2010) Structural Characteristics and Evolution of Chardzhou and Bukhara Terraces in the Amu Darya Basin, Middle Asia. Marine Origin Petroleum Geology, 15, 48-56.

[11] Wang, Q., Yan, X., Xu, W.L., Zheng, R.C., et al. (2014) Sequence-Paleogeographic Characteristics and Evolution of Callovian-Oxfordian in Amu Darya Basin, Turkmenistan. Geology and Exploration, 50, 0795-0804. (In Chinese)

[12] Zheng, R.C., Chen, H.R., Wang, Q., et al. (2014) The Reservoir Characteristics and Their Controlling Factors of Callovian-Oxfordian Carbonates in Amu Darya Basin. Acta Petrologica Sinica, 30, 779-788. (In Chinese)

[13] Yu, Y., Yin, J., Zheng, J., et al. (2015) Hydrocarbon Accumulation and Favorable Objectives in the Amu Darya Basin, Central Asia. International Journal of Production Economics, 181, 145-153. (In Chinese)

[14] Xu, J., Cheng, X., Wu, L., et al. (2010) Structural Evolution and Hydrocarbon Pooling Conditions in the Amu Darya Right Bank Block, Turkmenistan. Natural Gas Industry, 30, 18-20.

[15] Guo, Y.Q., Liu, L.F., Zhu, S.L., et al. (2006) Classification and Assessment of Petroleum System in Amu-Daria Basin. Petroleum Exploration \& Development, 33, 515-520. (In Chinese) 